\title{
PENGETAHUAN SISWA TENTANG PERILAKU BERESIKO TERJADINYA HUBUNGAN SEKSUAL PRANIKAH
}

\author{
Taufik Hidayat ${ }^{*}$, Normaidah \\ Program Studi Diploma Tiga Keperawatan Stikes Intan Martapura, Indonesia \\ Email : taufikakperintan@gmail.com
}

\begin{abstract}
ABSTRAK
Siswa merupakan bagian dari tahap perkembangan remaja yang berisiko mencoba melakukan hal negatif seperti hubungan seksual pranikah. Tujuan penelitian untuk mengetahui gambaran pengetahuan siswa tentang perilaku beresiko terjadinya hubungan seksual pranikah di SMAN 2 Karau Kuala. Metode penelitian menggunakan desain deskriptif sederhana dengan pendekatan studi potong lintang. Responden penelitian sebanyak 86 orang siswa pada kelas X dan XI. Instrumen penelitian menggunakan kuesioner dengan 30 pertanyaan. Hasil penelitian menunjukkan proporsi hampir sama yaitu 50,5\% berpengetahuan baik dan hanya $13 \%$ berpengetahuan kurang tentang perilaku berisiko terjadinya hubungan seksual pranikah, sisanya adalah berpengetahan sedang. Perlu dilaksanakan program pencegahan dan promosi kesehatan untuk menghindari perilaku terjadinya hubungan seksual pranikah melalui peningkatan pengetahuan siswa.
\end{abstract}

Kata Kunci : pengetahuan, risiko, perilaku, hubungan seksual

\section{ASTRACT}

Students are part of the developmental stage of adolescents who are at risk of trying to do negative things such as premarital sex. The purpose of the study was to describe students' knowledge about risky behavior for premarital sexual intercourse at SMAN 2 Karau Kuala. The research method uses a simple descriptive design with a crosssectional study approach. Research respondents were 86 students in class $X$ and XI. The research instrument used a questionnaire with 30 questions. The results showed almost the same proportion, namely $50.5 \%$ had good knowledge and only $13 \%$ had less knowledge about risky behavior for premarital sexual intercourse, the rest were moderate. It is necessary to implement a health promotion and prevention program to avoid premarital sexual intercourse behavior through increasing students' knowledge.

Keywords: knowledge, risk, behavior, sexual relationship

Cite this as : $\quad$ Hidayat T. (2021). Pengetahuan Siswa tentang Perilaku Beresiko Terjadinya Hubungan Seksual Pranikah. Jurnal Ilmu Kesehatan Insan Sehat, 9(1), 24-29.

\section{PENDAHULUAN}

Fase remaja adalah sebuah fase dimana terjadi perubahan secara pesat pada segi fisik, psikologis, intelektual, dan sosial. Pada masa ini remaja mengalami kematangan fisik/biologis dalam struktur organ tubuh, khususnya yang organ tubuh yang berhubungan dengan sistem reproduksi. Secara psikologis, fase ini akan meningkatkan sifat http://jurnalstikesintanmartapura.com/index.php/jikis keingintahuan, berani menanggung risiko terhadap perbuatan yang dilakukan, menyukai tantangan dan petualangan (Papalia, Olds, \& Fieldman, 2010).

Situasi ini akan membawa remaja terlibat berbagai masalah sosial, ekonomi, kejahatan, dan kesehatan remaja seperti perkelahian, persekusi dan bullying, minuman beralkohol dan penggunaan nafza, malnutrisi dan obesitas, perilaku merokok, trauma, dan 
Taufik Hidayat, Normaidah, Pengetahuan Siswa tentang Perilaku Beresiko

perilaku beresiko melakukan seksual tanpa nikah (Sarwono, 2011).

CDC melaporkan sekitar $41 \%$ dari 1,2 miliar remaja di dunia yang berusia 10-19 tahun diperkirakan telah melakukan hubungan seksual intim (Center for Disease Control and Prevention, 2015). Hasil survey perilaku seksual remaja pada tahun 2011 di Jakarta, Depok, Bogor, Bekasi, Tangerang, Yogyakarta, Bali, Bandung, dan Surabaya melaporkan sebanyak 39\% remaja pernah melakukan hubungan seksual intim saat berusia 15-19 tahun, 61\% saat berusia 20-25 tahun. Beberapa penelitian lain melaporkan remaja pertama kali melakukan hubungan seksual antara usia 14-23 tahun, dan terbanyak pada usia 17-19 tahun (Fuad et al, 2014). Proporsi ini menyimpulkan bahwa setiap 10 orang remaja maka 4 orang telah melakukan hubungan seksual.

BKKBN dalam laporannya pada tahun 2011 sebanyak 63\% remaja di beberapa kota besar di Indonesia telah melakukan hubungan seks pranikah. Beberapa persepsi remaja yang salah merupakan faktor yang memicu terjadinya perilaku tersebut. Remaja beranggapan bahwa hubungan seks yang dilakukan satu kali tidak akan menyebabkan kehamilan.

Perilaku terjadinya hubungan seksual pranikah dimulai dari perilaku seksual yang berisiko menyebabkan hal tersebut seperti berpacaran, Perilaku berpacaran pada remaja sering mengarah pada perilaku seperti berpegangan tangan, merangkul pasangan, sampai pada berciuman dan perabaan pada alat vital / reproduksi. Dewi dan Wiarsih (2011) melaporkan pada survei 72 remaja di wilayah Kota Depok sebanyak 52.8 $\%$ remaja mempunyai motivasi tinggi untuk berpacaran. Pada kegiatan Fokus Group Discussion (FGD) sebanyak $37.5 \%$ remaja menyatakan bahwa berciuman bibir adalah perilaku berpacaran yang masih dalam batas wajar.

Menurut Green dalam Notoatmojo (2012) Perilaku individu termasuk remaja dipengaruhi oleh faktor predisposisi/ pendukung, pemungkin, dan pendorong. Faktor predisposisi merupakan faktor yang mendasari niat dan motivasi individu melakukan sebuah perilaku tertentu. Faktor pemungkin adalah faktor yang menfasilitasi sehingga memungkinkan individu melakukan perilaku yang sudah termotivasi oleh faktor predisposisi. Faktor pendorong adalah faktor yang memperkuat dorongan perilaku untuk bertindak. Dari ketiga faktor tersebut, sumber dari individu berperilaku tertentu bermula dari faktor predisposisi yaitu adanya niat dan motivasi, sedangkan faktor lainnya hanya merupakan faktor yang mefasilitasi dan mendorong terjadinya perilaku tersebut (Notoatmojo, 2012)

Faktor predisposisi ini meliputi pengetahuan, persepsi, motivasi, sikap, niat, dan lain lain. Faktor yang berhubungan dengan pengetahuan merupakan faktor penting dalam ranah faktor predisposisi ini. Studi literatur yang dilakukan Hardiyati, Iskandar, dan Hernawaty (2019), menyatakan bahwa pengetahuan tentang seksualitas merupakan faktor yang berhubungan dengan perilaku seksual di kalangan remaja.

Minimnya pengetahuan tentang seksualitas menyebabkan remaja sulit untuk menghindari perilaku hubungan seks bebas (BKKBN, 2010). Tidak adekuatnya informasi yang akurat tentang kesehatan reproduksi, menjadi salah sebab masih rendahnya pengetahuan tersebut.

Survei Demografi Kesehatan Indonesia (SDKI) tahun 2013 melaporkan pengetahuan remaja tentang reproduksi dan seksualitas masih rendah pada remaja berusia $15-19$ tahun yaitu sebesar 31,2\% remaja lakilaki dan 35,5\% remaja perempuan berpersepsi bahwa perempuan bisa hamil hanya dengan sekali melakukan hubungan intim. Begitu juga dengan informasi tentang penyakit-penyakit yang akan dialami jika melakukan hubungan seksual seperti HIV, hanya sebesar 9,9\% remaja perempuan dan 10,6\% laki-laki mempunyai pengetahuan yang baik terhadap penyakit HIV-AIDS (Infodatin Kemenkes RI, 2020).

Selain dari masih rendahnya pengetahuan remaja secara kualitatif, pengetahuan tentang seksualitas terkait hubungan seksual pranikah juga rendah secara kalitatif. Minimnya literasi remaja terhadap tingkat akurasi informasi karena pengetahuan tersebut dari sumber - sumber yang tidak valid. Informasi dan pengetahuan umumnya diperoleh dari teman sebaya sesama remaja, atau dari buku fiksi yang seringkali menjurus ke arah fornografi yang selalu menceritakan tentang kesenangan tanpa mengungkapkan sisi akibat dari perilaku-perilaku seksual.

Peningkatan pengetahuan tentang dampak negatif melakukan hubungan seksual pranikah perlu terus dipromosikan untuk meningkatkan kuantitas pengetahuan remaja, disaat bersamaaan penyediaan literasi yang akurat dan benar juga perlu terus diberikan untuk meningkatkan kualitas pengetahuan.

Beberapa data diatas menunjukkan kondisi resiko perilaku seksual pranikah remaja yang cukup mengkhawatirkan. Menghadapi masalah tersebut diperlukan pendekatan yang komprehensif dan 
multidisiplin dengan peran serta seluruh komponen yaitu pemerintah, masyarakat, keluarga, dan tenaga kesehatan profesional. Langkah awal untuk mengetahui sejauh mana pengetahuan remaja terhadap resiko perilaku hubungan seksual pranikah remaja adalah dengan melakukan survei atau penelitian tentang hal tersebut.

\section{METODE}

Penelitian ini merupakan penelitian deskriptif sederhana menggnakan pendekatan studi potong lintang I cross sectional. Populasi adalah siswa remaja kelas X dan XI di SMAN 2 Karau Kuala Kabupaten Barito Selatan Kalimantan Tengah yang berjumlah 86 orang. Teknik pengambilan sampel menggunakan metode cluster random sampling.

Variabel dalam penelitian ini adalah variabel tunggal yaitu pengetahuan tentang perilaku berisiko terjadinya hubungan seksual pranikah. Instrumen penelitian menggunakan Kuesioner 30 pertanyaan yang terdiri dari 10 pertanyaan tentang faktor yang mempengaruhi perilaku berisiko terjadi hubungan seksual pranikah, 10 pertanyaan tentang penyebab perilaku berisiko terjadinya hubungan seksual pranikah, dan 10 pertanyaan tentang bentuk-bentuk perilaku berisiko terjadi hubungan seksual pranikah. Analisis data menggunakan analisis univariat yaitu dengan menyajikan data hasil penelitian dengan distibusi frekuensi dan persentase.

\section{HASIL}

\section{Tabel 1: Data umum responden}

\begin{tabular}{llll}
\hline No & Item Demografi & $\mathbf{N}$ & $\mathbf{\%}$ \\
\hline 1. & Usia (tahun) & & \\
\cline { 2 - 4 } & $14-16$ & 31 & 36 \\
\cline { 2 - 4 } & $17-18$ & 55 & 64 \\
\hline Jumlah & $\mathbf{8 6}$ & $\mathbf{1 0 0}$ \\
\hline
\end{tabular}

2. Jenis Kelamin

\begin{tabular}{lll}
\hline Laki - laki & 26 & 30.2 \\
\hline Perempuan & 60 & 69.8 \\
\hline
\end{tabular}

\begin{tabular}{llll}
\hline \multicolumn{1}{l}{ Jumlah } & $\mathbf{8 6}$ & $\mathbf{1 0 0}$ \\
\hline 3. & Agama & & \\
\cline { 2 - 3 } & Islam & 84 & 97.6 \\
\cline { 2 - 3 } & Kristen & 1 & 1.2 \\
\cline { 2 - 3 } & Katolik & 1 & 1.2 \\
\hline Jumlah & $\mathbf{8 6}$ & $\mathbf{1 0 0}$ \\
\hline
\end{tabular}

Respoden pada penelitian mayoritas berusia 17 - 18 tahun sebesar $64 \%$, berasal dari kelas X dan XI. Mayoritas responden berjenis kelamin perempuan sebesar $69.8 \%$ dengan pemeluk agama mayoritas Islam sebesar $97.6 \%$

Tabel 2: Tingkat Pengetahuan Tentang Perilaku Berisiko Terjadinya Hubungan Seksual Pranikah

\begin{tabular}{llll}
\hline No. & Tingkat Pengetahuan & N & \% \\
\hline 1. & Baik & 48 & 55.8 \\
\hline 2. & Sedang & 27 & 31.4 \\
\hline 3. & Kurang & 12 & 13.8 \\
\hline Jumlah & $\mathbf{8 6}$ & $\mathbf{1 0 0 . 0}$
\end{tabular}

Sebagian besar tingkat pengetahuan tentang perilaku berisiko terjadinya hubungan seksual pranikah responden pada kategori baik sebesar $55.8 \%$, hanya $13.8 \%$ responden berada dalam kategori berpengetahuan kurang.

Tabel 3: Tingkat Pengetahuan Terkait Faktor Yang Berpengaruh, Penyebab, Dan Bentuk Perilaku Berisiko Terjadinya Hubungan Seksual Pranikah

\begin{tabular}{llll}
\hline No & Item Pengetahuan & N & \% \\
\hline 1. & Faktor yang berpengaruh & & \\
\cline { 2 - 4 } & Baik & 47 & 54.6 \\
\cline { 2 - 4 } & Sedang & 34 & 40.2 \\
\cline { 2 - 4 } & Kurang & 5 & 5.2 \\
\hline Jumlah & 86 & 100 \\
\hline 2. & Penyebab & & \\
\cline { 2 - 4 } & Baik & 58 & 67.4 \\
\cline { 2 - 4 } & Sedang & 16 & 18.6 \\
\cline { 2 - 4 } & Kurang & 12 & 14 \\
\hline Jumlah & 86 & 100 \\
\hline 3. & Bentuk Perilaku & & \\
\cline { 2 - 4 } & Baik & 60 & 69.8 \\
\cline { 2 - 4 } & Sedang & 19 & 22.1 \\
\cline { 2 - 4 } & Kurang & 8.1 \\
\hline Jumlah & 86 & 100 \\
\hline
\end{tabular}

Mayoritas pengetahuan responden tentang faktor yang mempengaruhi perilaku terjadinya hubungan seksual pranikah baik sebesar 54.6\%, hanya $5.2 \%$ yang kurang. Pada pengetahuan tentang penyebab dan bentuk perilaku terjadinya hubungan seksual pranikah sebagian besar berkatagori baik yaitu sebanyak $67.4 \%$ dan $69.8 \%$, dan hanya $14 \%$ dan 8.1 $\%$ berpengetahuan kurang 


\section{PEMBAHASAN}

Tingkat pengetahuan individu menggambarkan seberapa banyak pengetahuan seseorang tentang subyek yang dijadikan fonomena yang dimilikinya. Menurut Bloom dalam Notoatmodjo (2012), pengetahuan mempunyai beberapa tingkatan, yaitu (1) Tahu (know) yaitu kemampuan individu mengingat suatu materi yang telah dipelajari sebelumnya; (2) Memahami (Comprehension) yaitu kemampuan individu menjelaskan tentang fenomena sebagai hasil dari tahu (know) dan dapat menginterpretasi pengetahuan tersebut secara benar; (3) Aplikasi (Application) yaitu kemampuan untuk menggunakan/ mengaplikasikan pengetahuan tersebut pada situasi nyata; (4) Analisis (Analysis) yaitu kemampuan menjabarkan pengetahuan atau objek atau fenomena kedalam komponen / kelompok yang sejenis atau berhubungan dan kemudian dapat menghasilkan kesimpulan; (5) Sintesis (Synthesis) adalah kemampuan mengelompokkan dan menghubungkan bagian pengetahuan kedalam bentuk / bagan yang baru; (6) Evaluasi (Evaluation) adalah kemampuan menilai terhadap obyek / fenomena tertentu (Notoatmodjo, 2012). Pada akhirnya tingkat pengetahuan yang baik akan menuju kepada kemampuan individu untuk dapat memberikan penilaian / justifikasi terhadap suatu fenomena. Kemampuan penilaian ini akan memberikan pilihan / alternatif perilaku yang akan diadopsi dimana masingmasing perilaku tersebut secara bersamaan akan selalu dibarengi dengan konsekuensinya masing-masing pula.

Hasil penelitian pada tabel 2 yang telah dilakukan terhadap pengetahuan siswa terkait risiko perilaku seksual pranikah di SMA Negeri 2 Karau Kuala dengan 86 responden menunjukkan lebih dari separuh responden berkategori pengetahuan baik yaitu berjumlah 48 orang $(55.8 \%)$, sementara siswa yang mempunyai pengetahuan pada katagori kurang hanya 12 orang responden $(13.8 \%)$. Besarnya proporsi ini mengindikasikan bahwa siswa kelas X dan XI sebagian besar telah memahami tentang perilaku berisiko terjadi hubungan seksual pranikah, sehingga peluang risiko terjadinya hubungan seksual pranikah semakin kecil.

Besarnya proporsi tingkat pengetahuan dalam katagori baik pada siswa salah satunya karena sekolah sudah semakin aktif dan peduli tentang kesehatan reproduksi remaja. Revitalisasi program UKS semakin meningkat sehingga semakin banyak transfer informasi melalui berbagai macam kegiatan penyuluhan kesehatan. Studi yang dilakukan oleh Israwati (2011)
Normaidah, Pengetahuan Siswa tentang Perilaku Beresiko pada 22.877 orang remaja di 33 provinsi di Indonesia melaporkan bahwa

Sumber informasi kesehatan reproduksi remaja diperoleh dari media, sekolah, petugas, dan dari teman, tetangga atau keluarga. Sebagian besar informasi diperoleh dari sekolah yaitu sebesar 70,5\% .

Penelitian Aziz, Ratag, dan Asrifuddin (2018) di kota Manado melaporkan adanya hubungan signifikan antara pengetahuan remaja tentang kesehatan reproduksi dengan perilaku seksual pranikah. Studi terdahulu yang dilakukan oleh Wibowo, Olfah, dan Sulistyaningsih (2013) juga telah memperlihatkan hasil yang sama yaitu adanya hubungan antara tingkat pengetahuan tentang kesehatan reproduksi dengan sikap terhadap perilaku seks bebas pada remaja siswa SMA N 1 Sewon Bantul I Yogyakarta. Hasil penelitian ini juga menunjukkan adanya hubungan yang kuat diantara variable tersebut yaitu sebesar 0,652.

Menurut informasi yang didapat dari staf pengajar di SMA Negeri 2 Karau Kuala menyampaikan bahwa siswa kelas $\mathrm{X}$ dan XI pengetahuan tentang seksualitas telah didapatkan melalui pelajaran dalam kurikulun inti Pendidikan sekolah menengah seperti pada mata pelajaran biologi dan pendikan jasmani. Siswa juga pernah mendapatkan informasi dari beberapa penyuluhan terkait masalah Kesehatan reproduksi pada remaja yang diberikan di sekolah sehingga pemahaman terhadap perilaku berisiko terjadinya hubungan seksual pranikah relatif baik.

Survei yang dilakukan Pakasi dan Kartilawati (2013) terhadap 918 siswa dan 128 guru SMA pada delapan kota di Indonesia melaporkan bahwa materi kesehatan reproduksi masuk dalam sub mata ajar di beberapa mata ajar pada kurikulum sekolah terutama di pelajaran Biologi $(72,7 \%)$, Bimbingan konseling (72,7\%), Agama (72,7\%), dan Pendidikan Jasmani Kesehatan dan Olahraga (Penjaskesor) (68\%).

Pendidikan Kesehatan seperti penyuluhan penyuluhan kesehatan di sekolah atau masyarakat dapat meningkatkan pengetahuan. Studi yang dilakukan Mursudarinah dan Fatmawati (2016) pada 80 orang responden siswa SMK di Surakarta menyimpulkan adanya pengaruh pendidikan kesehatan terhadap peningkatan pengetahuan remaja tentang perilaku seks pranikah. Studi ini juga mencatat adanya kenaikan proporsi tingkat pengetahuan pada katagori baik sebelum dan sesudah penyuluhan yaitu $47.5 \%$ menjadi $56.25 \%$.

Remaja yang mempunyai pengetahuan dalam katagori rendah hanya $13.8 \%$. Meskipun proporsi ini 
cukup rendah akan tetapi juga perlu diperhatikan bahwa responden dalam penelitian ini adalah siswa pada kelas $\mathrm{X}$ dan XI yang berarti mereka sudah hampir mencapai batas atas dalam fase usia remaja. Sebagian besar responden telah mencapai usia 17 - 18 tahun (64\%), padahal pendidikan tentang seksualitas dimulai dari remaja usia 10 tahun (BKKBN, 2010).

Pendidikan kesehatan reproduksi dan seksualitas bagi remaja secara dini sangat penting. Hal ini dimaksudkan untuk menghindari dampak negatif dari perilaku seksual yang tidak bertanggungjawab yang menimbulkan kerugian dari berbagai pihak, tidak hanya dari pihak remaja itu sendiri. Hasil Survei Demografi dan Kesehatan Indonesia (SDKI) Tahun 2017, melaporkan sebagian besar remaja perempuan (81\%) dan remaja laki-laki (84\%) telah berpacaran. Dari proporsi tersebut, sebesar $44 \%$ laki-laki dan $45 \%$ remaja perempuan diusia 15-17 tahun mulai mencoba berpacaran. Mayoritas remaja meyampaikan ketika berpacaran telah berperilaku seperti meraba atau diraba sebesar $22 \%$ pada laki-laki dan $5 \%$ perempuan; berciuman bibir sebesar $50 \%$ pada laki-laki dan $30 \%$ pada perempun; saling berpelukan sebesar $33 \%$ pada laki-laki dan $17 \%$ pada perempuan; dan berpegangan tangan sebesar $75 \%$ pada laki-laki dan $64 \%$ pada perempuan. (BKKBN,2019), https://www.bkkbn.go.id

Hasil penelitian pada tabel 3 juga menunjukkan bahwa diantara sub variabel yang paling banyak responden dalam katagori kurang pengetahuan tentang penyebab terjadinya perilaku berisiko melakukan hubungan seksual pranikah yaitu sebesar $14 \%$. Perilaku berpacaran merupakan perilaku umum yang terjadi pada remaja, padahal perilaku ini adalah penyebab awal bagi perilaku selanjutnya yang lebih intim yang dapat mengakibatkan terjadinya kehamilan tidak diinginkan pada usia belia dan di luar pernikahan. Perilaku hubungan intim ini juga dapat menyebabkan penularan penyakit seksual (PMS) (BKKBN, 2010).

Fenomena ini juga dipengaruhi oleh layana kesehatan reproduksi bagi remaja. Menurut Kemenkes RI (2013), melaporkan proporsi remaja berusia 15 - 19 tahun yang mengetahui layanan informasi dan konseling kesehatan reproduksi bagi remaja hanya 5.4 $\%$ remaja laki-laki dan $7.2 \%$ remaja perempuan, selebihnya belum mengetahui. Kurang pengetahuan tentang adanya layanan ini, hampir dipastikan hanya sedikit sekali remaja dapat mengakses layanan tersebut.

Upaya peningkatan pengetahuan tentang kesehatan reproduksi pada remaja perlu terus dilakukan dan dikembangkan melalui penyebarluasan informasi seperti sosialisasi, penyuluhan, dan penyediaan layanan kesehatan reproduksi. Upaya ini sebagai bagian dari tercapainya ketahanan remaja.

Program pembinaan ketahanan remaja merupakan program untuk mempersiapkan remaja sehingga dapat mencapai (1) jenjang pendidikan formal yang optimal melalui perencanaan yang terukur; (2) memperoleh jenjang karir dalam pekerjaan sesuai minat dan cita-cita; dan (3) menikah pada usia yang matang secara fisik, psikologi, dan sosial sesuai dengan kaidah kesehatan reproduksi melalui pemberian kemudahan akses informasi, konseling, pendidikan, dan pelayanan tentang perencanaan kehidupan berkeluarga. (BKKBN,2019), https://www.bkkbn.go.id

Program pembinaan untuk meningkatkan Ketahanan Remaja merupakan program yang penting untuk menciptakan remaja yang adaftif dan berkualitas. Hal ini berhubungan dengan asumsi bahwa : (1) remaja adalah individu yang berada pada fase akan memasuki kelompok usia produktif, sehingga akan mempengaruhi keberhasilan pembangunan dimasa yang akan datang; (2) remaja merupakan individu calon orangtua dalam sebuah keluarga berperan mengasuh anak-anaknya dengan pola asuh yang baik sehingga juga perlu dipersiapkan agar memiliki kesiapan berkeluarga melalui perencanaan yang matang. Kesiapan menjadi orangtua yang handal adalah salah satu faktor kunci untuk membangun keluarga yang adaftif terhadap segala perubahan hidup, yang pada kelanjutannya mampu melahirkan generasi yang berkualitas pula. (BKKBN,2019), https://www.bkkbn.go.id

\section{KESIMPULAN}

Tingkat pengetahuan siswa tentang perilaku berisiko terjadinya hubungan seksual pranikah sebagian besar dalam katagori baik (55.8\%). Hanya $13.8 \%$ siswa yang mempunyai pengetahuan kurang. Perlu tindak lanjut berupa kegiatan yang dapat meningkatkan pengetahuan siswa tentang perilaku berisiko ini khususnya tentang faktor penyebab terjadinya perilaku berisiko terjadinya hubungan seksual pranikah.

\section{DAFTAR PUSTAKA}

Azis, Sitti Rahmi Husaini. Ratag, Budi T, Asrifuddin, Afnal, (2018), Hubungan Antara Pengetahuan Dan Sikap Tentang Kesehatan Reproduksi Dengan Perilaku Seksual Pranikah Pada Remaja Di Kos-Kosan Kelurahan Kleak Kota Manado; Jurnal KESMAS, Volume 7 Nomor 4, Universitas Sam Ratulangi ; Manado 
Taufik Hidayat, Normaidah, Pengetahuan Siswa tentang Perilaku Beresiko

BKKBN (2010), Kesehatan Reproduksi Remaja. Kemenkes RI, (2016). Modul Kesehatan Reproduksi Jakarta.

BKKBN, (2019) Kesehatan Reproduksi Dan Nikah Dini -https://www.bkkbn.go.id

Center for Disease Control and Prevention (CDC), (2015), Youth Risk Behavior Survailance ; United states.

Dewi, Ari Pristiana \& Wiarsih, Wiwin (2012), Hubungan Karakteristik Remaja, Peran Teman Sebaya, dan Paparan Pornografi dengan Perilaku Seksual Remaja di Kelurahan Pasir Gunung Kota Depok, Tesis. Tidak Dipublikasikan.

Fuad et al, (2014) Pengaruh Pendidikan Kesehatan

Seksual Terhadap Pengetahuan dan Sikap Remaja Dalam Upaya Pencegahan Penyakit Menular HIV/AIDS di Kodya Yogyakarta. Berita Kedokteran Masyarakat XIX/IXI-60; UGM Yogyakarta.

Hardiyati, Shelly Iskandar, Taty Hernawaty (2019), Studi Literatur: Predisposing, Enabling, Dan Reinforcing Factors Perilaku Seksual Pranikah Pada Remaja , Jurnal Kesehatan Manarang Volume 5, Nomor 2, pp. 95 - 105 ISSN 25285602 (Online), ISSN 2443-3861

Papalia, Diane E., Old, Saly Wendkos, Feldman, Ruth Dustin (2010). Human Development, 9th Edition. USA; The McGraw Hill Companies.

Sarwono, (2011), Psikologi Remaja ed revisi. Jakarta: Raja Gravindo Persada.

Wibowo, Dwi Chandra Hari, Olfah, Yustiana, Sulistyaningsih, (2013), Hubungan Tingkat Pengetahuan Kesehatan Reproduksi Dengan Sikap Remaja Terhadap Perilaku Seks Bebas Di Sma Negeri 1 Sewon Bantul, Skripsi, Universitas Achmad Yani; Yogyakarta. 